\title{
First record sheds light on the distribution of the cyprinodontiform genus Jenynsia \\ (Günther, 1866) in the High Andean Plateau
}

Firpo Lacoste, F. $\Omega$, Andreoli Bize J.* and Fernandez L.*§

\begin{abstract}
${ }^{\Omega}$ Ministerio de Ambiente y Desarrollo Sostenible de la Nación and División Ictiología, Museo Argentino de Ciencias Naturales "Bernardino Rivadavia" (MACN); Ciudad Autónoma de Buenos Aires, Argentina, fflacoste@ambiente.gob.ar; *Centro Ictiológico Andino, Facultad Ciencias Exactas y Naturales, Universidad Nacional Catamarca, Catamarca, Argentina, julietaandreolibize@gmail.com; §CONICET, Fundación Miguel Lillo, Tucuman, Argentina, luis1813@yahoo.com
\end{abstract}

\begin{abstract}
This is the first record of the genus Jenynsia in the High Andean Plateau (HAP). It has been found at elevations between 3,400 to $3,900 \mathrm{~m}$ in three endorreheic systems: Salar Antofalla, Antofagasta de la Sierra, and El Peñón, Northwestern of Argentina, South America. This finding increases the number of known HAP fish genera to five. Furthermore, in contrast to the old andean species-rich genus Orestias, the presence of Jenynsia obscura populations in young high altitude non-marine saline wetlands reported here supports a recent dispersal into the HAP.
\end{abstract}

This article has been accepted for publication in the Journal of Fish Biology and undergone full peer review but has not been through the copyediting, typesetting, pagination and proofreading process, which may lead to differences between this version and the Version of Record. Please cite this article as doi: 10.1111/jfb.14525

This article is protected by copyright. All rights reserved. 
Key words: Puna, Catamarca, Cyprinodontiformes, Northwestern Argentina, Jenynsia obscura

The Andean Plateau is the largest continental-scale high plain on the Earth associated with abundant magmatism located above a $3 \mathrm{~km}$ elevation contour extended from $13^{\circ} \mathrm{S}$ to $27^{\circ} \mathrm{S}$. This wide South American topographic feature was originated in lower Miocene ( 25 Ma) through a vicariant multi-stage uplift that, in the southernmost part called Puna, lasted until 1-2 Ma (Allmendinger et al. 1997). The HAP is characterized by extensive evaporitic bodies acting as collectors of a closed drainage network subject to an arid climate and a wide daily thermal amplitude (Risacher et al. 2003). This landscape is dominated by nonmarine brines accumulated in sedimentary basins during Neogene, where ecological heterogeneity is expressed by an array of aquatic ecosystems that include numerous extensive salars and lagoons — such as Antofalla and Laguna Colorada - as well as geothermal springs and other high altitude wetlands (Alonso et al. 1991, Benzaquen et al. 2017). Within the entire HAP, that stretches along $1800 \mathrm{~km}$ from southern Perú Altiplano plain to Northwestern Argentina Puna, only four native fish genera were recorded above 3 km: Astroblepus (climbing catfish), Orestias and Pseudorestias (pupfish), and Trichomycterus (pencil catfish) (Arraya et al. 2009, Barra et al. 2009, Schaefer 2011, CruzJofré et al. 2014, Arratia et al. 2017, Fernandez \& Andreoli Bize 2017, 2018). The Orestiini (sensu Arratia et al. 2017) is recognized as the sole cyprinodontiform clade found in the 
HAP. By comparison, the complementary distribution of Anablepidae is considered the outcome of a Neogene diversification in South American coastal marine habitats (Nelson et al. 2016, Amorim \& Costa 2018). This family has a quite dissimilar richness. Whereas two of its genera comprise few coastal species from Central America and Northern South America, most of the species-rich genus Jenynsia is known to be distributed in several small freshwater wetlands across southern South America, from the Central Andes foothills to Atlantic basins and coastal environments (Ghedotti 2003, Frota et al. 2019). Jenynsia obscura (Weyenbergh 1877) (= J. pygogramma Boulenger 1902) is one of the species from the Central Andean foothills (Ringuelet et al. 1967, Aguilera et al. 2013).

We hereby report the first record of Jenynsia obscura in the Puna, between 3,400 to 3,900 masl. Twelve specimens of Jenynsia obscura were recognized by the following combination of characters: $22-23$ scales in the predorsal series; $35-36$ scales in the lateral line series; very fine line of pigments along the lateral series in the middle of the flank and some vertical spots close to the mid-dorsal line (Koerber \& Azpelicueta 2009) (Fig. 1). These fishes were captured at elevations above the limit of the Puna: Salar Antofalla 3,950 m, El Peñón and Antofagasta de la Sierra at 3,400 m in Catamarca province, Argentina (Fig. 2). The specimens were kept alive, later anesthetized with benzocaine and killed by immersion in cold water $\left(0^{\circ} \mathrm{C}\right)$ in situ (Metcalfe \& Craig 2011). Then were fixed in $10 \%$ formalin and preserved in $75 \%$ ethanol in the Ichthyological Collection of the Facultad de Ciencias Exactas y Naturales, Universidad Nacional de Catamarca, Argentina (FACEN). Extensive ichthyological surveys in the Puna indicate that Jenynsia is absent in many 
suitable wetlands (LF pers. obs.) but J. obscura populations are well established among the small rocky bottom vegetated creeks and ponds reported here (Fig. 1, Suppl. Video).

The distribution of most Jenynsia species is uneven across wetlands located below the HAP from 2,300 $\mathrm{m}$ to seashore. While J. luxata, J. tucumana and J. sulfurica are reported to occur in few localities of northwestern Argentina, J. maculata, J.

alternimaculata and J. obscura, exhibit a more extended regional coverage in what appears to show some degree of endemism; in contrast, J. lineata is widely distributed in the vast plains of central Argentina, from Atlantic coastal environments to Andean foothills (Buti \& Miquelarena 1995, Ghedotti 2003, Menni et al. 2005, Aguilera et al. 2013, Amorim 2018; Frota et al. 2019 and references therein). The distribution of J. obscura encompasses many endorrheic riverine wetlands associated with the easternmost Sierras Pampeanas ranges at Cruz del Eje river (type locality, $470 \mathrm{~m})$ and Conlara river $(675 \mathrm{~m})$ to the south. Both basins have their base level $(180 \mathrm{~m})$ in Salinas Grandes salt flat. In addition to our records, this species is also present to the west well beyond Salinas Grandes in Andean foothills up to 2,000 m, thus exhibiting a continuous distribution (Ringuelet et al. 1967).

The finding of J. obscura in such an unusual location for the Anablepidae like high altitude evaporitic volcanic environments of the Puna shown here, pose some interesting issues in the midst of a current discussion on the adaptive radiation of the genus. The debate focuses on the events that led a cyprinodontiform clade to the invasion of inland wetlands, and the role of the marine-freshwater transitions during marine incursions recorded in Neogene times (Amorim \& Costa 2018). In this regard, Amorim \& Costa 
(2019) have recently proposed that a transition across osmotic barriers towards sea coastal environments evolved during Pleistocene in the clade embracing J. lineata and J. darwini. Ichthyologists have long considered $J$. lineata highly tolerant to salinity levels and have recently been recorded to occur in the Rio de la Plata estuary under influence of marine water for the first time (Ringuelet et al. 1967, Menni et al. 1996, Guerrero et al. 1997, Menni 2004, Calviño \& Alonso, 2016). Moreover, its presence in strictly marine environments was followed by the ichthyology staff of the Museo Argentino de Ciencias Naturales (MACN) since 1947 through 1961 in Mar del Plata sea shore and have also been found in San Blas tidal flat of South Atlantic Ocean. Indeed this species has even been reported in the hypersaline Epecuén lagoon $\left(37^{\circ} 07^{\prime} 52,27^{\prime \prime} \mathrm{S} 62^{\circ} 52^{\prime} 44,65^{\prime \prime} \mathrm{W}\right)$ when salinity was near twice marine levels (López et al. 1993). Likewise, among west Andean species, cox1 gene divergence suggests a recent origin for tolerant microendemic $J$. sulfurica (Aguilera et al. 2019). Physiological issues apart, Miocene diversity of Anablepidae was higher than present as revealed by paleoicthyological studies. Extinct taxa from northwestern Argentina found in ancient coastal facies supports an earlier hypothesis about the strong influence of the middle Miocene marine transgressive phase on the distribution of Jenynsia (Aguilera \& Mirande 2005, Sferco et al. 2017). Furthermore, late Miocene deposits of "Puchuzum" ephemeral lacustrine environments yielded additional evidence to support an anablepid ongoing adaptive radiation (Bogan et al. 2018). Interestingly, these conditions are analogous to those of Salinas Grandes-Ambargasta system around which $J$. obscura and J. lineata co-occur. This arid tectonic depression once harboured a huge 
endorrheic lacustrine system (Laguna Grande-Laguna de Ambargasta) that may have lasted from upper Pleistocene to middle Holocene, and was fed in various stages through the Sali river Andean drainage whose channels diverted as a result of Sierras Pampeanas basement uplift since the middle of the Pliocene (Gutiérrez et al. 2017). Since then until Pleistocene extensive tectonic activity took place in the Puna, and also at the eastern edge of the Salar de Antofalla. Here, faulting and thrusting reduced the saltpan basin to its present elongated shape until the end of Middle Pleistocene, (Kraemer et al. 1999). Nevertheless, just as much as Quaternary seismic activity diminished, large amounts of modern alluvial fan deposits like Vega El Colorado were shed (Hongn \& Seggiaro 2001, Seggiaro et al. 2007). Hence, the finding of J.obscura populations amidst young non-marine evaporitic wetland environments strongly suggests that the late geophysical stability of the Puna allowed a recent dispersal. Finally, this finding contributes to the long needed historical biogeographic assessment of HAP fish diversity (Parenti 1984).

\section{Material Examined}

J. obscura: FACEN 31, 3 specimens, Los Nacimientos, 279'52.84’'S 6644'41.33’W, 2,019 m, 9 July 2016; FACEN 122, 5 specimens, El Peñón, Antofagasta de la Sierra, $26^{\circ} 28^{\prime} 49.19^{\prime \prime S} 67^{\circ} 15^{\prime} 14.78^{\prime \prime} \mathrm{W}, 3,440$ m, 12 October 2018; FACEN 124, 2 specimens, Villa Vil, 275'58.72’S 66²9’38.90’W, 2,186 m, 13 October 2018; FACEN 143, 4 specimens, Laguna Colorada, Antofagasta de la Sierra, 26¹'57.00’'S 67²6’54.67’W, 3,400 m, 12 October 2018; FACEN 158, 8 specimens, Laguna Colorada, Antofagasta de la 
Sierra, 26¹'57.00’S 67²6’54.67’’W, 3,400 m, 11 December 2019, FACEN 123, 3

specimens, Salar Antofalla, Antofagasta de la Sierra, 25³5’39.64’S 67³0’49.38’'W, 3,950

m, 12 October 2018; FACEN 145, 4 specimens, Saujil, Fiambalá, 27³4’05.40’S

67³7’14.43’W, 1,615 m, 14 April 2019; MACN-Ict 5306, 15 specimens, Río Salado, cerca de Bazán, 296’23.17’S 6640’33.00’W, 521 m, 14 October 1949, Col. Sr. Rossi

J. lineata: All located at sea level. MACN-Ict 4274, 5 specimens, Laguna El Ostral, Puerto de Mar del Plata, Col. López, 13 April 1954; MACN-Ict 4121, 10 specimens, Mar del Plata, Col. López, 8 March 1947; MACN-Ict 6583, 78 specimens, Mouth of Punta Mogotes stream, Mar del Plata, 29 April 1961; MACN-Ict 4271, 1 specimen, Ría de San Blas, San Blas Bay, 25 January 1952, Col. Siccardi.

The authors gratefully acknowledge the assistance given by the Instituto Biodiversidad Neotropical (IBN) and Museo Argentino de Ciencias Naturales "Bernardino Rivadavia” (MACN). This study was partially supported by the research project PICTI-IPR (Universidad Nacional Catamarca). We also thank Secretaría de Ambiente y Fauna de Catamarca and Ministerio de Ambiente y Desarrollo Sostenible de la Nación (MAyDS). We would also like to thank S. Coll (UNCA) who revised our manuscript. Two anonymous reviewers and M. C. Mirande comments, greatly improved an earlier version of this communication. 


\section{References}

Aguilera, G., Mirande, J.M., Calviño, P.A. \& Lobo L.F. (2013). Jenynsia luxata, a new species from northwestern Argentina, with additional observations of J. maculata Regan and phylogeny of the genus (Cyprinodontiformes: Anablepidae). Neotropical Ichthyology $11,565-572$.

Aguilera, G. \& Mirande, J.M. (2005) A new species of Jenynsia (Cyprinodontiformes, Anablepidae) from northwestern Argentina and its phylogenetic relationships. Zootaxa 109, 29-39.

Allmendinger, R. W., Jordan, T.E., Kay, S.M. \& Isacks, B. L. (1997). The evolution of the Atiplano-Puna Plateau of the central Andes. Annual Review of Earth and Planetary Sciences 1997 25, 139-74.

Alonso R.N., Jordan, T.E. Tabbutt, K.T. \& Vandervoort, D.S. (1991). Giant evaporite belts of the Neogene central Andes. Geology 19, 401-404.

Amorim P. F. (2018) Jenynsia lineata species complex, revision and new species description (Cyprinodontiformes: Anablepidae). Journal of Fish Biology, 92, 1312-1332. Amorim P.F. \& Costa, W.J.E.M. (2018). Multigene phylogeny supports diversification of four-eyed fishes and one-sided livebearers (Cyprinodontiformes: Anablepidae) related to major South American geological events. PLoS ONE, 13(6):e0199201.

Amorim P.F. \& Costa, W.J.E.M. (2019). Reconstructing biogeographic temporal events in the evolution of the livebearer fish genus Jenynsia based on total evidence analysis (Cyprinodontiformes: Anablepidae). Systematics \& Biodiversity 7, 124-133. 
Arratia, G., Vila I., Lam N., Guerrero C.J. \& Quesada-Romegialli C. (2017).

Morphological and taxonomic descriptions of a new genus and species of killifishes

(Teleostei: Cyprinodontiformes) From the high Andes of Northern Chile. PLoS ONE 12

(8): e088181989.

Arraya, M.M., Maldonado, M., Carvajal-Vallejos, F.M. \& Fernandez, L. (2009).

Contribución al conocimiento de los peces del género Trichomycterus (Siluriformes:

Trichomycteridae) en los Andes de Bolivia. Revista Boliviana de Ecología y

Conservación Ambiental 26, 45-52.

Barra, E., Maldonado, M., Carvajal-Vallejos. F. \& Coronel, J.S. (2009). The killifish

Orestias in the Bolivian Puna. Revista Boliviana de Ecología y Conservación Ambiental

26, 1-7.

Benzaquen, L., Blanco, R. Bo, P. Kandus, G. Lingua, Minotti, X. \& Quintana, R. (2017).

Regiones de Humedales de la Argentina. Ministerio de Ambiente y Desarrollo

Sustentable, Fundación Humedales/Wetlands International, Universidad Nacional de San

Martín y Universidad de Buenos Aires. 333 pp. ISBN: 978-987-29811-6-7.

Bogan, S., Contreras, V.H., Agnolin, F., Tomassini, R.L. \& Peralta, S. (2018) New genus

and species of Anablepidae (Teleostei, Cyprinodontiformes) from the Late Miocene from

Argentina. Journal of South American Earth Sciences 88, 374-384.

Buti, C.\& Miquelarena, A. (1995) Ictiofauna del Río Salí superior, departamento Trancas, Tucumán, República Argentina. Acta Zoologia Lilloana, 43 (1) 21-42, 
Calvino, P. \& Alonso, F. (2016) First record of the genus Jenynsia from marine water on the coast of Punta del Este, Maldonado, Uruguay (Cyprinodontiformes: Anablepidae). Journal of Fish Biology, 88, 1236-1240

Cruz-Jofré, F., Morales, P., Esquer-Garrigos, Y, Vila, I., Hugueny, B., Gaubert, P. \& Méndez, M.A. (2014). Taxonomic identity of the forms of Orestias agassii (Teleostei: Cyprinodontidae) from Chile: A morphological comparison with the syntypes of the species of Peru and Bolivia. Gayana 78, 41-45.

Fernández, L. \& Andreoli Bize, J.M. (2017). Trichomycterus alterus (Marini, Nichols \& La Monte, 1933) and T. corduvensis Weyenberg 1877 (Siluriformes: Trichomycteridae): new records from the High Andean Plateau. Check List Journal of biodiversity data 13, 2068. ISSN 1809-127X.

Fernandez, L. \& Andreoli Bize, J.M. (2018). New species of Trichomycterus (Siluriformes: Trichomycteridae) from the High Andean Plateau of Argentina. Zootaxa 4504, 359-370. Frota, A., Pavanelli, C.S. \& Da Graca, W.J. (2019) Areas of endemism for Anablepidae (Teleostei: Cyprinodontiformes): A monophyletic family of freshwater fishes in the Neotropics. Zootaxa 4671, 527-540.

Ghedotti, M.J. (2003) Family Anablepidae (Four eyed fishes, onesided live bearers and the white eye), p. 582-585. In: Check List of the Freshwater Fishes of South and central America. R. E. Reis, S. O. Kullander, and C. J. Ferraris, JR. (eds.). Edipucrs, Porto Alegre, Brazil. 
Guerrero, R.A., Acha, M.E., Framiñan, M.E., Lasta, C., 1997. Physical oceanography of the Río de la Plata estuary. Continental Shelf Research 17 (7), 727-742.

Gutiérrez, A.A., Mon, R. \& Suvires, G.M. (2017). La red de drenaje del borde oriental andino y de la llanura central argentina, indicadora de movimientos tectónicos recientes. In: Muruaga, C.M. y Grosse, P. (Eds.), Ciencias de la Tierra y Recursos Naturales del NOA. Relatorio del XX Congreso Geológico Argentino, San Miguel de Tucumán: 646669. ISBN 978-987-42-6666-8

Hongn, F. \& Seggiaro, R.E. (2001) Hoja Geológica 2566-III, Cachi. Provincias de Salta y Catamarca. Instituto de Geología y Recursos Minerales, Servicio Geológico Minero Argentino. Boletín 248, 87 p. Buenos Aires.

Koerber, S. \& Azpelicueta, M.M. (2009). On two Jenynsia taxa (Cyprinodontiformes: Anablepidae) from Argentina, originally placed in the poeciliid genus Xiphophorus. Zootaxa 2028, 51-58.

Kraemer, B., Adelmann, D., Alten, M., Schnurr, W., Erpenstein, K., Kiefer, E., van den Boogard, P. \& Görler, K. (1999) Incorporation of the Paleogene foreland into the Neogene Puna plateau: The Salar de Antofalla area, NW Argentina. Journal of South American Earth Sciences 12, 157-182.

López, H.L., Padín, O.H. \& Iwaszkiw, J.M. (1993). Biología pesquera de las lagunas Encadenadas del Sudeste, Provincia de Buenos Aires. ProBiota, FCNyM, UNLP, Serie Documentos 9, 1-110. ISSN 1666-731X. 
Menni, R.C. (2004) Peces y ambientes en la Argentina Continental. Monografia Museo Argentino de Ciencias Naturales 5, 1-316, 2004. Buenos Aires. ISSN 1515-7652

Menni, R.C., Miquelarena, A.M., \& Volpedo A.V. (2005) Fishes and environment in northwestern Argentina: from lowland to Puna. Hydrobiologia 544, 33-49.

Menni R.C., Gómez, S.E. \& López Armengol, F. (1996). Subtle relationships: freshwater fishes and water chemistry in southern South America. Hydrobiologia 328, 173-197.

Metcalfe, J. D., \& Craig, J. F. (2011). Ethical justification for the use and treatment of fishes in research: An update. Journal of Fish Biology, 78, 393-394.

Nelson, J. S.; T. Grande \& M. V. H. Wilson (2016) Fishes of the World. 5th ed. John Wiley \& Sons. New Jersey. 707 p.

Parenti, L.R. (1984). Biogeography of the Andean killifish genus Orestias with comments on the species flock concept. In: A. A. Echelle \& I. Kornfeld (eds.) Evolution of fish species flocks (pp. 85-92) Maine. University of Maine at Orono Press.

Parker, A. \& Kornfield, I. (1995). Molecular perspective on Evolution and Zoogeography of Cyprinodontid Killifishes (Teleostei; Atherinomorpha). Copeia 1995, 8-21.

Ringuelet, R.A., Arámburu, R.R. \& Alonso de Arámburu, A.S. (1967). Los peces argentinos de agua dulce. La Plata. Comisión de Investigaciones Científicas de la Provincia de Buenos Aires.

Risacher, F., Alonso, H. \& Salazar, C. (2003). The origin of brines and salts in Chilean salars: a hydrochemical review. Earth Science Reviews 63, 249-293. 
Schaefer, S.A. (2011). The Andes: Riding the tectonic uplift. In: Albert, J.S., P. Petry \& R.E. Reis (eds). Historical biogeography of Neotropical freshwater fishes, p 259-279, Berkeley University of California Press.

Seggiaro, R., Becchio, R., Pereyra, F. \& Martínez, L. (2007) Hoja Geológica 2569-IV, Antofalla, provincias de Catamarca y Salta. Instituto de Geología y Recursos Minerales. Servicio Geológico Minero Argentino, Boletín 343, 62 p. Buenos Aires.

Sferco, E., Herbst, R., Aguilera, G., \& Mirande, J.M. (2017) The rise of internal fertilization in the Anablepidae (Teleostei, Cyprinodontiformes): Two new genera and species from the Miocene of Tucumán, Argentina. Papers in Palaeontology, 4, 177-195. 
Figure 1. Specimens and habitats of Jenynsia obscura. Top. Left, FACEN 143, male specimen, $26.2 \mathrm{~mm}$ SL; right FACEN 122, female specimen, 38.0 mm SL. Center. Left: El Peñon, 3,400 m. Right: Antofagasta de la Sierra, 3,400 m. Bottom. Left: Subaquatic view at El Peñon, note shoal at the center of the picture. Right: Vega El Colorado, eastern edge of Salar de Antofalla, 3,950 m.

Figure 2. Map of Jenynsia obscura records in Catamarca, Argentina (green dot). High Andean Plateau is depicted in greyscale, and dark green for lands below 3,000 m, (Source map: GTOPO30-DEM, USGS-EROS). Inset: High Andean Plateau is indicated; light green frame show magnification of the view on the left.

Supporting information video. Underwater video of Jenynsia obscura in its habitat at El Peñón, Puna plains in Catamarca, Argentina. 


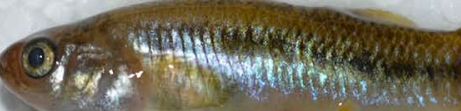

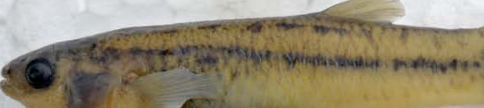

est $=5$

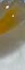

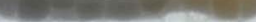

\section{P}

- 1 -

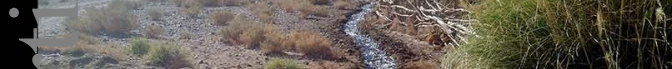

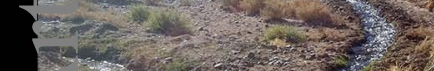

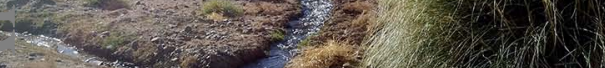

4

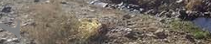

(3)

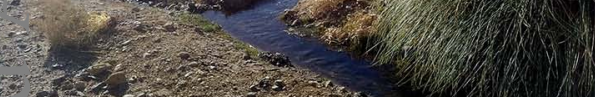

(6:

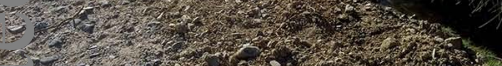

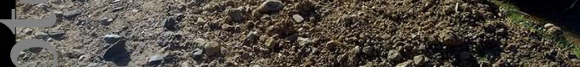

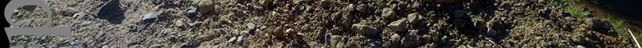

(1)

$\left(\begin{array}{l}1 \\ \text { i } \\ 0\end{array}\right.$

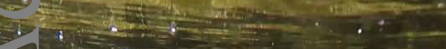

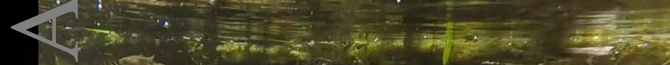
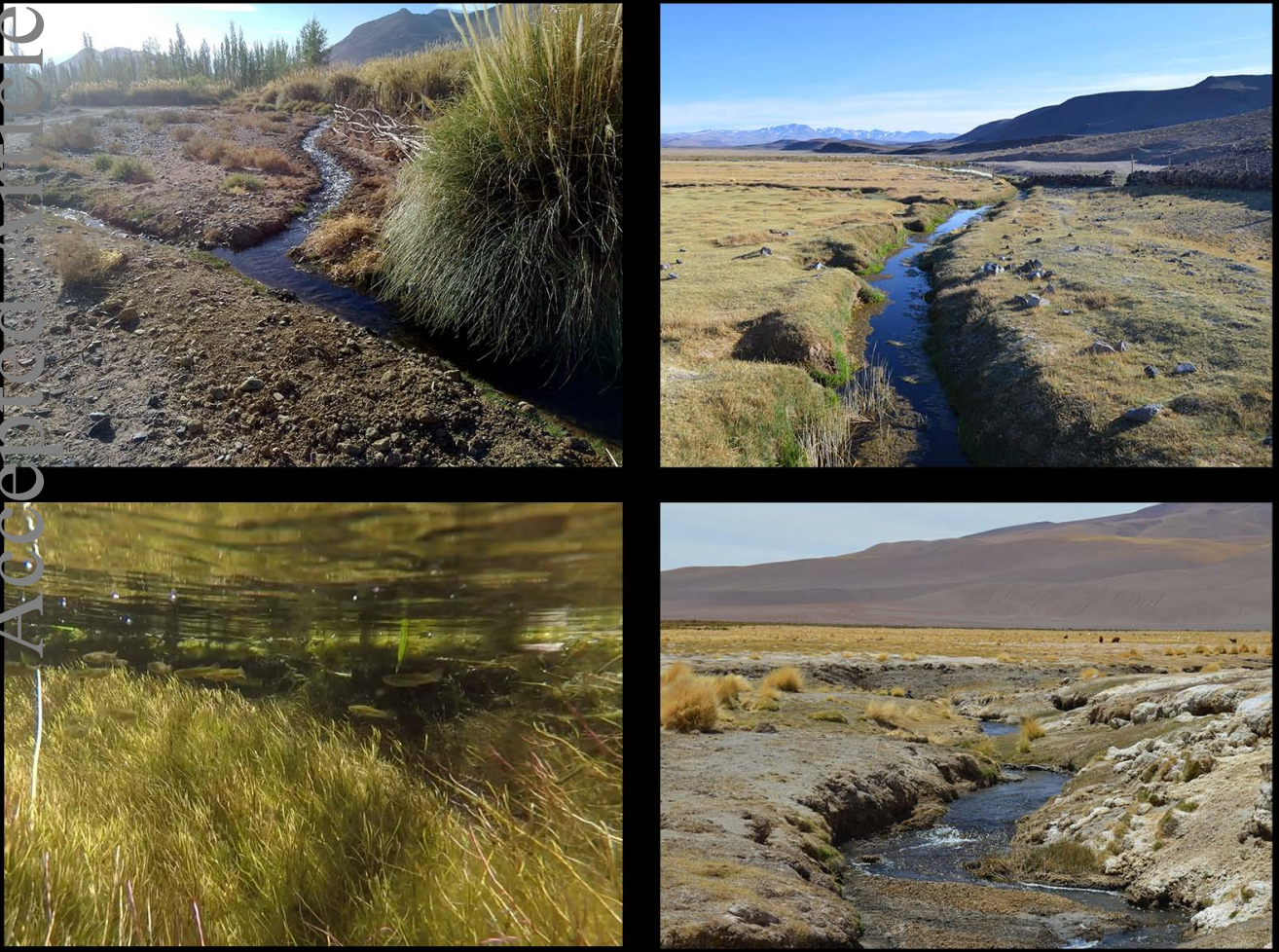


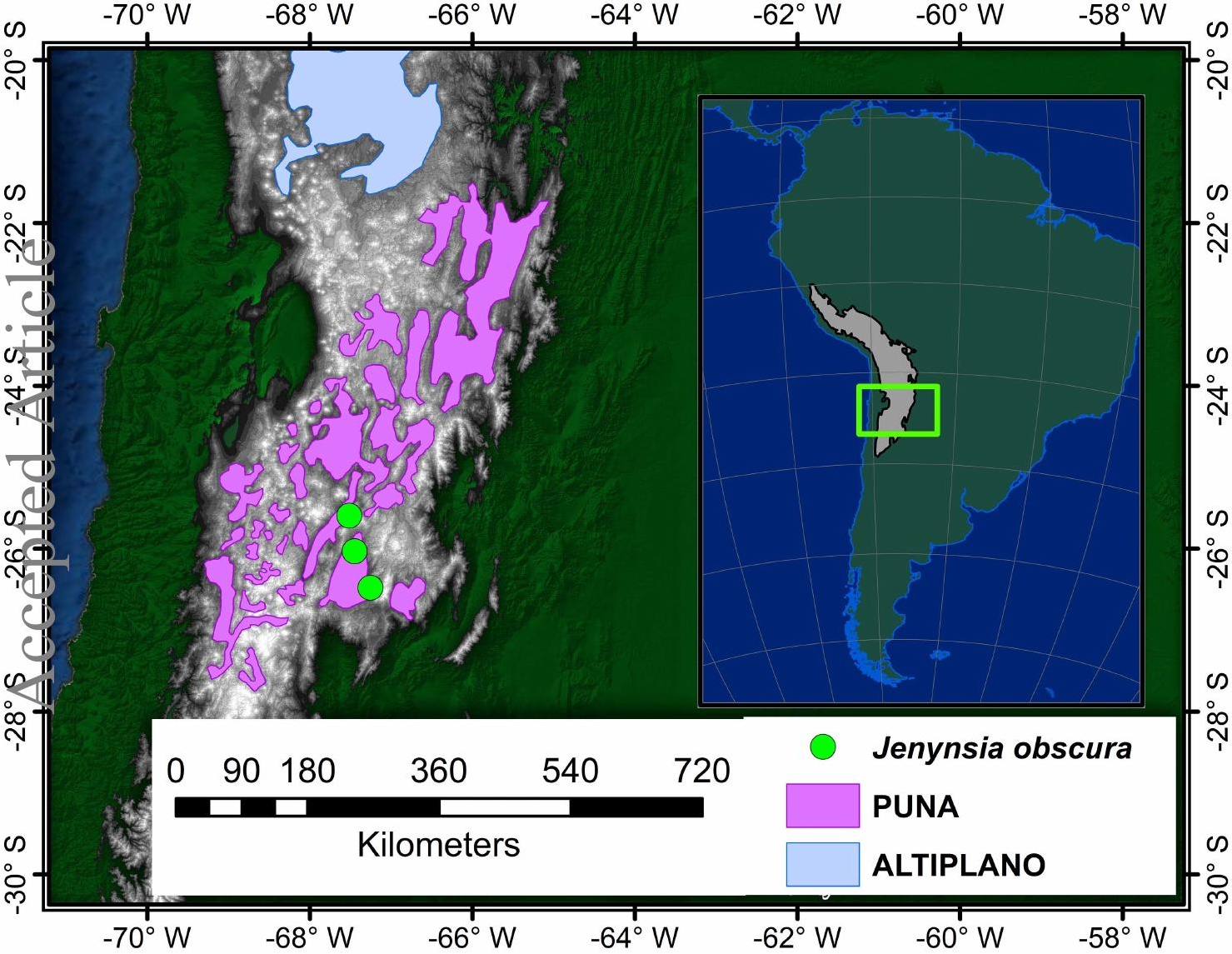

